\title{
Viability of Staphylococcus xylosus during shelf-life of dulce de leche prepared by vacuum evaporation
}

\author{
Viabilidade de Staphylococcus xylosus na vida de prateleira de doce de leite elaborado em \\ evaporador a vácuo
}

\author{
Alexandre José Cichoski ${ }^{I}$ Ana Paula Cansian ${ }^{\text {II }}$ Marco Di Luccio ${ }^{\text {II }}$
}

\begin{abstract}
In this research an innovation in the manufacture of dulce de leche by vacuum evaporation is presented, based on the addition of Staphylococcus xylosus. The culture growth, lactic acid bacteria, $\mathrm{pH}$, acidity, water activity, and lactose and sucrose contents were monitored. The cell counting of $\boldsymbol{S}$. xylosus varied from $\log _{10} 6.22 \mathrm{cfu} \mathrm{g}^{-1}$ to $\log _{10} 6.83 \mathrm{cfu} \mathrm{g}^{-1}$. Lactic acid bacteria naturally occurring in the milk varied from $\log _{10}$ $3.62 c f u g^{-1}$ to $\log _{10} 4.38 c f u g^{-1}$ (90 th day of storage). The $\mathrm{pH}$ was favourable to the growth of $\boldsymbol{S}$. xylosus, showing the viability of using this culture in this kind of product.
\end{abstract}

Key words: dulce de leche, starter culture, dairy products, Staphylococcus xylosus.

\section{RESUMO}

Este trabalho apresenta uma proposta de inovação, que é a adição da cultura pura de Staphylococcus xylosus em doce de leite elaborado em evaporador a vácuo. Monitorou-se o desenvolvimento da cultura pura e das bactérias lácticas, o pH, a acidez, a atividade de água e os teores de lactose e sacarose. O número de colônias da cultura pura variou de $\log _{10} 6,22 u f c g^{-1}$ a $\log _{10} 6,83 u f c g^{-1}$, enquanto que as bactérias lácticas naturalmente presentes no doce variaram de $\log _{10} 3,62 u \mathrm{fc}_{\mathrm{c}} \mathrm{g}^{-1}$ a $\log _{10}$ 4,38ufc $g^{-1}$ no $90^{\circ}$ dia de armazenamento. $O$ valor de $\mathrm{pH}$ foi favorável ao crescimento do S. xylosus, demonstrando a viabilidade do uso da cultura neste tipo de produto.

Palavras-chave: doce de leite, cultura starter, produtos lácteos, Staphylococcus xylosus.

\section{INTRODUCTION}

Dulce de leche is a milk-based candy, prepared by slowly heating of sweetened milk, typically found in countries of Central and South America, but also with similar products found in France ("confiture de lait"). This product presents a basic composition similar to the sweetened condensed milk, but is normally prepared in an open cooker without vacuum; at 130$140^{\circ} \mathrm{C}$ for $1 \mathrm{~h}$. Variations on the operational conditions may be found. Depending on the cooking conditions, many changes in the product may occur, changing its nutritional characteristics (MALEC et al., 2005; CICHOSKI et al., 2005). The product colour may also vary from a light cream colour to a dark brown. This colour is a function of the degree of completeness of Maillard reactions that occur during cooking, which may also influence the product aroma and flavour (MALEC et al., 2005; CICHOSKI et al., 2006a).

Vacuum concentration can be used to concentrate a product under mild temperatures, minimizing the influence of high temperatures on the undesired reactions, and thus, on the nutritional and sensorial quality of the food (SINGH \& HELDMAN, 1993). The preparation of dulce de leche by vacuum evaporation has the main advantage of the use of mild temperatures in the process. Thus, the contents of protein, sugar and flavour compounds are less affected

'Departamento de Tecnologia e Ciência dos Alimentos, Universidade Federal de Santa Maria (UFSM), Campus Universitário, Prédio 42, Bairro Camobi, 97105-900, Santa Maria, RS, Brasil. E-mail: cijoale @gmail.com. Autor para correspondência.

"Departamento de Engenharia de Alimentos, Universidade Regional Integrada do Alto Uruguaia e das Missões (URI), Erechim, RS, Brasil. 
by cooking than when normal boiling temperatures are used. The nutritional properties of the end product are then maintained and flavour characteristics can be improved when compared to the product obtained by cooking at higher pressure, minimizing the off-flavours characteristic of overcooking.

Staphylococcus xylosus are Gram-positive and coagulase-negative bacteria, of the family Micrococcaceae. It occurs in the first few days of cheese ripening, when the $\mathrm{pH}$ is still above 5.0 (MOUNIER et al. 2008). Thus, this culture is little used as pure starter culture in cheese making. This culture is commonly used in cured and fermented meat products, with the main objective to develop flavour, aroma and texture (LÜCKE, 1994). Staphylococcus xylosus shows proteolytic and lipolytic activity, what may contribute to development of aroma and flavour in fermented meat products (STAHNKE, 1994; OLESEN et al., 2004). The application of such microorganisms in association to lactic acid bacteria has been investigated, to assess the application of such starters in aroma and flavour development (DALMIS \& SOYER, 2008; CASABURI et al., 2008).

The objective of this work was to assess the viability of using a starter culture, Staphylococcus xylosus in the production of dulce de leche by vacuum evaporation, aiming to introduce technological innovation in this kind of dairy product. It is worth noting that all kind of dulce de leche produced in South America do not include the addition of pure microbial cultures in their formulation.

\section{MATERIALS AND METHODS}

\section{Milk pre-concentration}

Thirty litres of standardised and pasteurised milk ( $1.3 \%$ fat) were concentrated in a vacuum cooker at $50^{\circ} \mathrm{C}$, vacuum pressure of $-0.825 \mathrm{kgf} \mathrm{cm}^{-2}$, stirring rate 170rpm for 20min (CICHOSKI et al., 2005).

Preparation of sugar syrup

The amount of sucrose used in all experiments was $20 \%(\mathrm{w} / \mathrm{w})$ in relation to the mass of pre-concentrated milk. Arabic gum was added to the solid sucrose in a ratio of $1 \mathrm{~g}$ of Arabic gum to each $1 \mathrm{~L}$ of non-concentrated milk. $25 \mathrm{~mL}$ of water were added to each $100 \mathrm{~g}$ of sucrose in the formulation. The mixture was heated to $110^{\circ} \mathrm{C}$ and then $2 \%(w / w)$ of glucose was added in relation to the sucrose mass. This syrup was stored at $10^{\circ} \mathrm{C}$ (CICHOSKI et al., 2005; 2006a; 2006b).

Preparation of the dulce de leche

The previously pre-concentrated milk was mixed with the sugar syrup and transferred to the vacuum evaporator. The candy was prepared at $50^{\circ} \mathrm{C}$, at a stirring speed $170 \mathrm{rpm}$, vacuum pressure $-0.825 \mathrm{kgf}$ $\mathrm{cm}^{2}$ for 20min (CICHOSKI et al., 2005; 2006a; 2006b). After cooking, the mass was divided into two parts. $25 \mathrm{~g}$ of lyophilised culture of $\boldsymbol{S}$. xylosus (Strain Flora Carn SX ${ }^{\circledR} 100$, Chr. Hansen) per kg of mass were added to one sample (the number of bacteria ranged from 5.7 to $5.9 \log \mathrm{cfu}^{-1}$ for all strains), hereby determined as "Test" sample. The other part of the mass was used for control experiments, where no culture was added. The candy was packed in $200 \mathrm{~mL}$-plastic jars with aluminium seal. The jars were stored for 120 days at $10^{\circ} \mathrm{C}$. The experiments were run in triplicates for evaluation of experimental error.

\section{Physico-chemical analysis}

The analyses of $\mathrm{pH}$, acidity, water activity, lactose and sucrose were carried out Just after product formulation (Day 0) and at the $120^{\text {th }}$ day of storage. Content of moisture, protein, oil and fat, and total soluble solids $\left({ }^{\circ} \mathrm{Brix}\right)$ was determined right after product formulation. Water activity $\left(\mathrm{a}_{\mathrm{w}}\right)$ was determined at $10^{\circ} \mathrm{C}$ in an Aqualab CX-2 Water Activity System, following the standard procedure described by the supplier. The calibration was carried out with a $6 \mathrm{M}$ solution of $\mathrm{LiCl}$ in deionised water.

Lactose was determined following the method described by FIL-IDF 28-A (1974). Protein, oil and fat, ashes and $\mathrm{pH}$ were determined following procedures described by AOAC (2000). Sucrose, Dornic acidity and total soluble solids ( ${ }^{\circ}$ Brix) were determined as described by IAL (2005).

Microbiological analysis

Microbiological analyses were carried out just after product formulation and at the $15^{\text {th }}, 30^{\text {th }}, 45^{\text {th }}$, $60^{\text {th }}, 75^{\text {th }}, 90^{\text {th }}$ and $120^{\text {th }}$ day of storage at $10^{\circ} \mathrm{C}$. The number of cells of $\boldsymbol{S}$. xylosus and lactic bacteria was determined following the procedure described by STAHNKE (1995), using mannitol salt agar (MSA) and Man, Rogosa \& Sharp agar (MRS), respectively, following incubation at $30^{\circ} \mathrm{C}$ for $72 \mathrm{~h}$.

\section{Statistical analysis}

The physico-chemical and microbiological analyses were carried out in triplicates. The results were analysed by analysis of variance, followed by Tukey's test, applied to verify the significance level between the averages $(\mathrm{P}<0.05)$, using the software Statistica 6.1 (STATSOFT INC, TULSA, OK, USA).

\section{RESULTS AND DISCUSSION}

The composition of the dulce de leche (Test and Control) right after production was $9.67 \%$ protein, 
9.30\% fat, $8.20 \%$ sucrose, $5.53 \%$ lactose, $2.00 \%$ ashes, $65.30 \%$ moisture and $54^{\circ} \mathrm{Brix}$. The $\mathrm{pH}$, acidity ( ${ }^{\circ}$ Dornic), $\mathrm{a}_{\mathrm{w}}$ and content of lactose and sucrose found in the samples are presented in table 1 .

At the $120^{\text {th }}$ day of storage, the product confectioned with pure culture (Test) presented higher $\mathrm{pH}$ than that found in the control product. The $\mathrm{pH}$ found in the Test sample was favourable for the growth of the pure culture of Staphylococcus xylosus, since $\mathrm{pH}$ lower than 5.7 inhibit the growth of this microorganism (STANHKE, 1995).

The acidity did not increase in the Test and Control samples, during the 120 days of storage at $10^{\circ} \mathrm{C}$. Consequently, no significant differences were observed. This result is confirmed by the low variations observed in the content of lactose and sucrose.

The plate count of Staphylococcus xylosus during storage are presented in figure 1. The number of colonies of Staphylococcus xylosus in the control sample (that naturally occurs in milk) varied from $\log _{10}$ $2.50 \mathrm{cfu} \mathrm{g}^{-1}$ to $\log _{10} 4.27 \mathrm{cfu} \mathrm{g}^{-1}$. In the Test samples, where a starter culture was added, the number of colonies varied from $\log _{10} 5.80 \mathrm{cfu} \mathrm{g}^{-1}$ to $\log _{10} 6.83 \mathrm{cfu} \mathrm{g}^{-1}$ (Figure 1). The cell counting in the Test samples was always higher than in the control product.

The strain Staphylococcus xylosus presents a good growth between $15^{\circ} \mathrm{C}$ and $45^{\circ} \mathrm{C}$, and can grow in $\mathrm{NaCl}$ concentrations up to $15 \%$, and in $\mathrm{pH}$ higher than 5.7 (GEISEN et al.,1992; STANHKE, 1995). The lowest $\mathrm{pH}$ in the Test sample was 6.36 (Table 1), which is higher than the growth inhibition limit for Staphylococcus xylosus. (CARRASCOSA \& CORNEJO, 1989).

Besides this positive characteristic presented by the Test sample, an important result was observed, which was the growth of Staphylococcus xylosus (Figure 1) at $10^{\circ} \mathrm{C}$ and at a sugar concentration of $13.73 \%$ (5.53\% lactose +8.20 sucrose, Table 1$)$. This behavior is remarkable, since the osmotic pressure obtained at such a high sugar concentration and low temperature could have inhibited its growth. This proves the possibility of using a pure culture of Staphylococcus xylosus in dulce de leche, aiming at helping with development of special aroma, taste and texture to such products.

The Test samples presented $a_{w}$ of 0.95 , which is lower than the water activity that favour the rapid growth of bacteria. Most of bacteria grow fast in $\mathrm{a}_{\mathrm{w}}$ between 0.99 to 0.98 . However, the cell counting of Staphylococcus xylosus did not decrease, remaining practically constant during all the storage time (Figure 1). This result is important, since it shows that the added culture remains viable throughout the time of storage. This behaviour may be explained by the ability of the Staphylococcus xylosus to grow in low $\mathrm{a}_{\mathrm{w}}$. This strain was already detected in matured and fermented meat products, which show $\mathrm{a}_{\mathrm{w}}$ between 0.86 and 0.85 (GARCIA et al., 1995; TERRA et al., 2007).

Different species of pure cultures of Staphylococcus xylosus have been added to traditional Italian salami ("salsiccia Vallo di Diano"), to induce proteolysis and lipolysis, improving flavour and aroma. During the processing and storage of this kind of meat product, the cell counting varied between $10^{6}$ and $10^{7} \mathrm{cfu} \mathrm{g}^{-1}$ (CASABURI et al., 2008).

In the present work, the cell counting of Staphylococcus xylosus in the Test samples during storage varied from $\log _{10} 6.22 \mathrm{cfu} \mathrm{g}^{-1}$ to $\log _{10} 6.83 \mathrm{cfu} \mathrm{g}^{-1}$, which is in accordance with the reported for Italian salami. This growth suggests that proteolysis may be occurring in the dulce de leche, what could improve aroma and taste of this product, evidencing the need of further studies that involve sensory analysis of the product. Further studies are thus needed for confirming this statement.

The evolution of naturally-occurring lactic bacteria is presented in figure 2 . The naturally occurring lactic bacteria count in the Control samples varied from $\log _{10} 3.41 \mathrm{cfu} \mathrm{g}^{-1}$ to $\log _{10} 5.14 \mathrm{cfu} \mathrm{g}^{-1}$, while in the Test samples this countings varied from $\log _{10} 3.62 \mathrm{cfu} \mathrm{g}^{-1}$ to

Table 1 - Acidity, $\mathrm{pH}, \mathrm{a}_{\mathrm{w}}$, lactose and sucrose content in the Test and Control samples.

\begin{tabular}{|c|c|c|c|c|}
\hline & \multicolumn{2}{|c|}{ 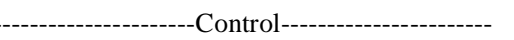 } & \multicolumn{2}{|c|}{----------------------Test----------------------- } \\
\hline & $0 \mathrm{~h}$ & $120 \mathrm{~h}$ & $\mathrm{Oh}$ & $120 \mathrm{~h}$ \\
\hline $\mathrm{pH}$ & $6.50 \pm 0.02^{\mathrm{a}}$ & $6.36 \pm 0.01^{\mathrm{b}}$ & $6.50 \pm 0.02^{\mathrm{a}}$ & $6.57 \pm 0.01^{\mathrm{a}}$ \\
\hline Acidity $\left({ }^{\circ}\right.$ Dornic) & $28.80 \pm 0.60^{\mathrm{a}}$ & $30.45 \pm 0.06^{\mathrm{a}}$ & $28.80 \pm 0.60^{\mathrm{a}}$ & $30.89 \pm 0.58^{\mathrm{a}}$ \\
\hline$a_{w}$ & $0.956 \pm 0.001^{\mathrm{a}}$ & $0.955 \pm 0.001^{\mathrm{a}}$ & $0.956 \pm 0.001^{\mathrm{a}}$ & $0.955 \pm 0.001^{\mathrm{a}}$ \\
\hline Lactose $(\%)$ & $5.53 \pm 0.06^{\mathrm{a}}$ & $5.52 \pm 0.04^{\mathrm{a}}$ & $5.53 \pm 0.06^{\mathrm{a}}$ & $5.41 \pm 0.07^{\mathrm{a}}$ \\
\hline Sucrose $(\%)$ & $8.20 \pm 0.10^{\mathrm{a}}$ & $8.28 \pm 0.05^{\mathrm{a}}$ & $8.20 \pm 0.10^{\mathrm{a}}$ & $8.33 \pm 0.03^{\mathrm{a}}$ \\
\hline
\end{tabular}

Different superscripts in the same line indicate significant differences $(\mathrm{P}<0.05)$, by Tukey's test. 


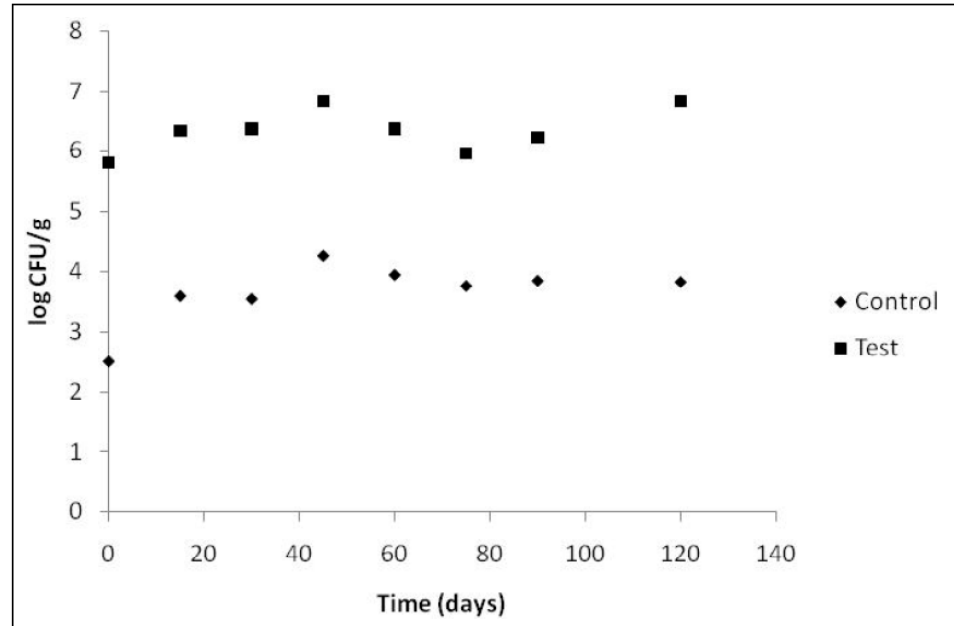

Figure 1 - Plate count of Staphylococcus xylosus $\left(\log _{10} \mathrm{cfu} \mathrm{g}^{-1}\right)$, in the test and control samples of the dulce de leche during storage at $10^{\circ} \mathrm{C}$.

$\log _{10} 6.08 \mathrm{cfu} \mathrm{g}^{-1}$ (Figure 2). No significant differences $(P>0.05)$ were observed between the Control and Test samples before the $60^{\text {th }}$ of storage. Studies on Cheddar cheese showed that the naturally occurring lactic bacteria countings varied from $\log _{10} 7.0$ to $\log _{10} 8.0$ after 3 months of storage. These bacteria converted the lactose to lactic acid and also induced the proteolysis and lipolysis, which contributed to the improvement of flavour and aroma of the final product. Moisture, protein, fat content and $\mathrm{pH}$ of the cheese were about $38 \%, 25 \%$, $32 \%$ and 5.5, respectively (EL SODA et al., 2000; FURTADO, 2005). In the present work, the Test dulce de leche presented final moisture $65.7 \%$, sugar $13.73 \%$ (8.20\% sucrose and $5.53 \%$ lactose), $9.67 \%$ protein, $9.30 \%$ fat and pH 6.50 (Table 1), while the counting of lactic acid bacteria after 3 months of storage was $\log _{10} 6.08 \mathrm{cfu}$ $\mathrm{g}^{-1}$ (Figure 2). Although the Test sample presented higher moisture content when compared to the Cheddar cheese, the number of lactic bacteria was lower, as well as $\mathrm{pH}$ could have been inadequate for the growth. Proteolysis could also have been hindered.

In the fermented meat product with addition of pure culture of Staphylococcus xylosus and Lactobacillus curvatus, CASABURI et al. (2008) verified that the higher degree of proteolysis occurred when this product was compared to the product without the addition of Lactobacillus. The proteolysis was correlated to the drop in $\mathrm{pH}$ due to the action of Lactobacillus curvatus, what favoured the action of indigenous proteolytic enzymes of the meat. The milk

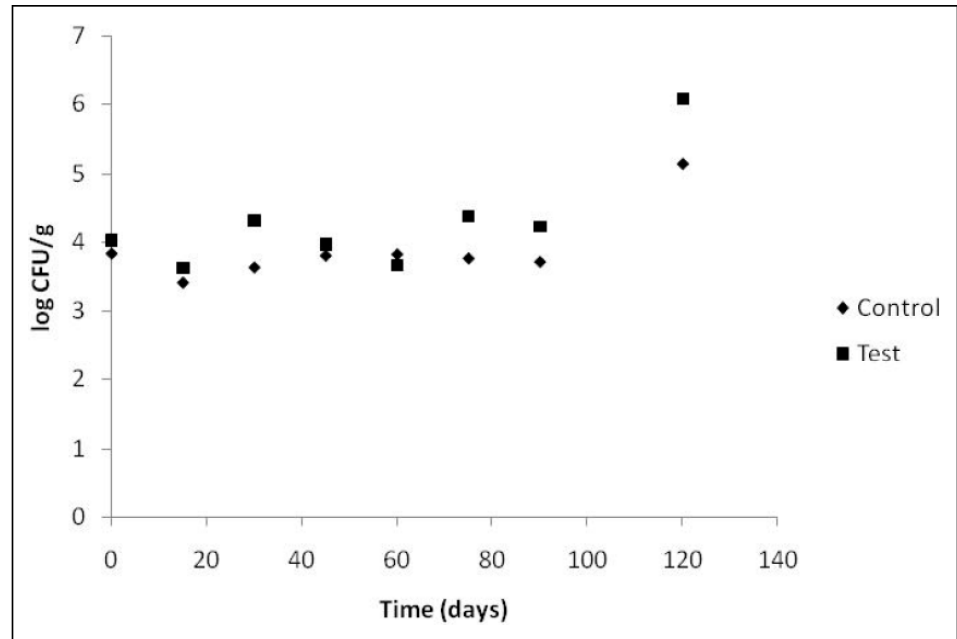

Figure 2 - Plate count of naturally occurring lactic bacteria $\left(\log _{10} \mathrm{cfu} \mathrm{g} \mathrm{g}^{-1}\right)$ in the test and control samples of dulce de leche during storage at $10^{\circ} \mathrm{C}$.

Ciência Rural, v.41, n.11, nov, 2011. 
contains the indigenous plasmin that works best at $\mathrm{pH}$ between 6.5 and 8.0 (SCOLLARD et al., 2000; MARTINS, 2006; CORTELLINO et al., 2006). This enzyme plays an important role in aroma and flavour development in Emmenthal and Gouda cheese production, due to its ability to induce proteolysis (VARNAM \& SUTHERLAND, 1995). In the present work, the number of lactic bacteria present in the Test samples was not able to reduce the $\mathrm{pH}$ of the product, which remained in the range favourable for the proteolytic action of plasmin.

\section{CONCLUSION}

The high sugar concentration and water activity of the "dulce de leche" did not inhibit the growth of the pure culture of Staphylococcus xylosus during storage for 120 days at $10^{\circ} \mathrm{C}$, showing the possibility of using this culture in the production of dulce de leche. The sugar concentration of $13.73 \%$ and water activity of 0.95 did not inhibit the growth of the pure culture of Staphylococcus xylosus during storage at $10^{\circ} \mathrm{C}$ for 120 days. These results suggest the need of further investigation concerning the aroma, taste and texture of dulce de leche with addition of Staphylococcus xylosus.

The countings of lactic acid bacteria that naturally occurs in the dulce de leche did not cause significant changes in the in the sugar (lactose and sucrose) content, and consequently in the acidity and $\mathrm{pH}$, thus not influencing the growth of the pure culture of Staphylococcus xylosus that was added to the product.

\section{REFERENCES}

AOAC. Association of Official Analytical Chemists. Official methods of analysis. 17.ed. Washington, 2000. 2000p.

CASABURI, A. et al. Proteolytic and lipolytic starter cultures and their effect on traditional fermented sausages ripening and sensory traits. Food Microbiology, v.25, p.335-347, 2008. Available from: <http://dx.doi.org/10.1016/j.fm.2007.10.006>. Accessed: Jul. 25, 2011. doi: 10.1016/j.fm.2007.10.006.

CARRASCOSA, A.V.; CORNEJO, I. Aspectos fisico-qumicos del curado de jamon serrano y su influencia sobre el desarrollo microbiano (Revisión). Alimentaria, v.195, p.27-33, 1989. CICHOSKI, A.J. et al. Influence of the vacuum time and stirring rate on protein content in dulce de leche produced in evaporator. Revista Leite e derivados, v.85, p.38-50, 2005.

CICHOSKI, A.J. et al. Color and soluble solids in dulce de leche produced at different vacuum conditions. Revista do Instituto de Laticínios Cândido Tostes, v.61, p.11-15, 2006a.

CICHOSKI, A.J. et al. Dulce de leche prepared in evaporator with low-fat and concentrated milk. Revista Higiene Alimentar, v.20, p.29-32, 2006b.
CORTELlinO, G. et al. An investigation of the plasminplasminogen system in caprine milk and cheese. International Dairy Journal, v.16, p.619-622, 2006. Available from: <http:/ /dx.doi.org/10.1016/j.idairyj.2005.11.012>. Accessed: Jul. 25, 2011. doi: 10.1016/j.idairyj.2005.11.012.

DALMIS, Ü.; SOYER, A. Effect of processing methods and starter culture (Staphylococcus xylosus and Pediococcus pentosaceus) on proteolytic changes in Turkihs sausage (sucuk) during ripening and storage. Meat Science, v.80, p.345-354, 2008. Available from: <http://dx.doi.org/10.1016/j.meatsci.2007.12.022>. Accessed: Jul. 25, 2011. doi: 10.1016/j.meatsci.2007.12.022.

EL SODA, M. et al. Adjunct cultures: recent developments and potential significance to the cheese industry. Journal of Dairy Science, v.83, p.609-619, 2000. Available from: <http:// dx.doi.org/10.3168/jds.S0022-0302(00)74920-4>. Accessed: Jul. 25, 2011. doi:10.3168/jds.S0022-0302(00)74920-4.

FURTADO, M.M. Main problems in cheese: causes and prevention. 2.ed. São Paulo: Fonte Comunicações e Editora, 2005. 200p.

GEISEN, R. et al. Starter and protective cultures for meat and meat products. Fleischwirtschaft, v.72, p.894-898, 1992.

IAL. Normas analíticas do Instituto Adolfo Lutz. Métodos químicos e físicos para análise de alimentos. 2.ed. São Paulo, 2005. 1018p.

INTERNATIONAL DAIRY FEDERATION (FIL-IDF). Standards of determination of the lactose content of cheese and processed cheese products. Brussels, Belgium, 1974. (FIL-IDF. D-Doc 28-A).

LÜCKE, F.K. Fermented meat products. Food Research International, v.27, p.299-307, 1994. Available from: <http:/ /dx.doi.org/10.1016/0963-9969(94)90098-1>. Accessed: jul. 25, 2011. doi: 10.1016/0963-9969(94)90098-1.

MARTINS, J.M. Physical-chemical and microbiological chractaristics in the maturation process of artisanal cheese. 2006. 146f. PhD (Thesis) - Federal Univeristy of Viçosa, MG, Brazil.

MALEC, L.S. et al. Loss of available lysine during processing of different Dulce de leche formulations. International Journal of Dairy Technology, v.58, p.164-168, 2005. Available from: <http://dx.doi.org/10.1111/j.1471-0307.2005.00202.x>. Acessed: Jul. 25, 2011. doi: 10.1111/j.1471-0307.2005.00202.x.

MOUNIER, J. et al. Microbial interactions within a cheese microbial community. Applied and Environmental Microbiology, v.74, p.172-181, 2008. Available from: <http://dx.doi.org/10.1128/AEM.01338-07>. Accessed: Jul. 25, 2011. doi: 10.1128/AEM.01338-07.

OLESEN, P.T. et al. The influence of environmental parameters on the catabolism of branched-chain amino acid by Staphylococcus xylosus and Staphylococcus carnosus. Food Microbiology, v.21, p.43-50, 2004. Available from: <http:// dx.doi.org/10.1016/S0740-0020(03)00048-0>. Accessed: Jul. 25, 2011. doi: 10.1016/S0740-0020(03)00048-0.

SCOLLARD, P.G. et al. Plasmin activity, b-lactoblobulin denaturation and proteolysis in high pressure treated milk. 
International Dairy Journal, v.10, p. 835-841, 2000. Available from: <http://dx.doi.org/10.1016/S0958-6946(01)00028-0>. Accessed: jul. 25, 2011. doi: 10.1016/S0958-6946(01)00028-0.

SINGH, D.P.; HELDMAN, D.R. Introduction to food engineering. 2.ed. San Diego: Academic, 1993. 499p.

STAHNKE, L.H. Aroma components from dried sausages fermented with by Staphylococcus xylosus. Meat Science, v.38, p.39-59, 1994. Available from: <http://dx.doi.org/ 10.1016/0309-1740(94)90094-9>. Accessed Jul. 25, 2011. doi: 10.1016/0309-1740(94)90094-9.

STAHNKE, L.H. Dried sausages fermented with Staphylococcus xylosus at different temperatures and with different ingredient levels - Part I. Chemical and bacteriological data. Meat Science, v.41, p.179-191, 1995. Available from: <http:// dx.doi.org/10.1016/0309-1740(94)00070-N>. Accessed: Jul. 25, 2011. doi: 10.1016/0309-1740(94)00070-N.

TERRA, N.N. et al. Water activity, $\mathrm{pH}$, moisture and growth of Staphylococcus xylosus during processing and storage of cured, matured and fermented pork shoulder. Ciência e Tecnologia de Alimentos, v.27, p.756-760, 2007. Available from: <http:/ /dx.doi.org/10.1590/S0101-20612007000400014>. Accessed: Jul. 25, 2011. doi: 10.1590/S0101-20612007000400014.

VARNAM, A.H.; SUTHERLAND, J.P. Leche y productos lácteos. Tecnología, química y microbiología. Zaragoza, Espanha: Acribia, 1995. 476p. 